\title{
Natural Area Weeds: A Property Owner's Guide to Melaleuca Control 1
}

\section{K.A. Langeland and M.J. Meisenburg ${ }^{2}$ \\ Introduction}

Melaleuca trees (Melaleuca quinquenervia) were brought to the United States from Australia in 1887 for use in landscaping, agricultural windrows, highway plantings, and soil stabilization. Natural areas of southern Florida were invaded by the exotic Melaleuca tree over 100 years ago. Aided by wind-dispersed seed, it rapidly spread and by 1994 there were nearly a half-million acres of melaleuca in southern Florida, with extensive stands in the Everglades, Big Cypress National Preserve, and Arthur R. Marshall Loxahatchee National Wildlife Refuge. Everglades National Park, one of the "crown jewels" of the National Park System, is threatened by stands of melaleuca encroaching from the east Everglades.

Melaleuca forms dense stands, called monocultures, that completely transform the character of natural habitats. It displaces native plant communities and associated wildlife, disturbs natural water flow, and alters soil conditions. Areas that were once home to endangered species such as the Cape

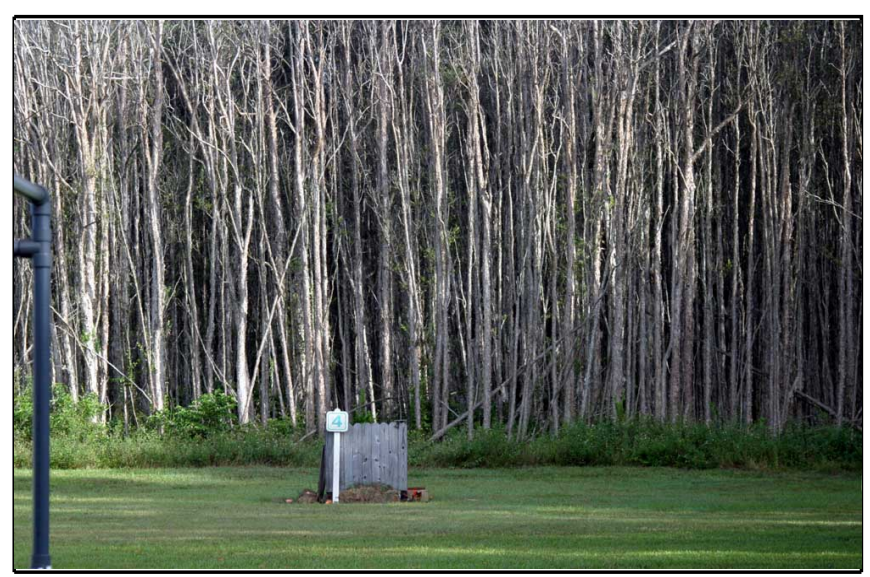

Figure 1. Infestation of melaleuca in Markham Park, Ft. Lauderdale, FL.

Sable seaside sparrow (Ammodramus maritimus mirabili), wood stork (Mycteria americana), and Florida panther (Puma concolor coryi) are no longer suitable due to melaleuca invasion. When fire occurs, melaleuca trees burn extremely hot, causing additional environmental destruction. The greatest negative impact of melaleuca may be to migrating birds, which depend on native plants to provide the seeds, fruits, and insects that have fueled their journeys for thousands of years. It is estimated that if

1. This document is SS-AGR-96, one of a series of the Agronomy Department, Florida Cooperative Extension Service, Institute of Food and Agricultural Sciences, University of Florida. Original publication date October 2005. Visit the EDIS Web Site at http://edis.ifas.ufl.edu.

2. K. A. Langeland, professor, Agronomy Department, Center for Aquatic and Invasive Plants; M. J. Meisenburg, graduate assistant, Agronomy Department; Florida Cooperative Extension Service, Institute of Food and Agricultural Sciences, University of Florida, Gainesville, FL 32611.

The use of trade names in this publication is solely for the purpose of providing specific information. UF/IFAS does not guarantee or warranty the products named, and references to them in this publication does not signify our approval to the exclusion of other products of suitable composition. It is illegal to use an herbicide in a manner inconsistent with the label's instructions; therefore, read the label carefully and follow the instructions. 
left uncontrolled, melaleuca could overtake much of Florida's remaining natural habitat by 2025 . In addition, it is predicted that its uncontrolled spread would significantly restrict the use of parks and recreation areas, which would negatively impact ecotourism.

Fortunately, something is being done. During the 1990s, agencies in Florida spent \$25 million to control melaleuca. The South Florida Water Management District, with an aggressive program to rid District lands of melaleuca, estimates that the problem can be contained within the Everglades Water Conservation Areas and marshes of Lake Okeechobee by 2009. Federal and state agencies have also cooperated in recent years to identify biological control agents and develop herbicide technology that can be used against melaleuca. To bring all of these efforts together, the USDA is cooperating with state agencies in a project known as The Areawide Management and Evaluation of Melaleuca quinquenervia, or "TAME Melaleuca."

Successful reduction of the melaleuca problem in Florida depends on a multifaceted management approach, called integrated pest management (IPM), that incorporates several methods of control including biological controls, mechanical control, and herbicides. Public participation is key to successful integrated management of melaleuca on public lands because melaleuca trees not controlled on private (and commercial) property are a constant source of wind-blown seed that can infest new areas and re-infest natural areas on public lands where trees have been controlled. This publication is one of a series with the purpose of providing information to empower citizens of Florida to protect Florida's natural areas from melaleuca and other invasive plant species.

\section{How to Recognize Melaleuca}

- Evergreen tree that averages 65 feet in height, single-trunked or multiple trunks.

- Thick, pale, papery bark that peels easily (Figure 2).

- Leaves are narrowly lance-shaped, up to 4 inches long and 3/4 inch wide, leathery, with three prominent veins, emitting a smell of camphor when crushed (Figure 3).

- Bottlebrush-shaped, creamy-white flowers in spikes up to 6 inches long (Figure 4) can occur throught the year, mainly from November through February with a peak in December.

- Seeds contained within persistent, woody capsules clustered on stems (Figure 5).

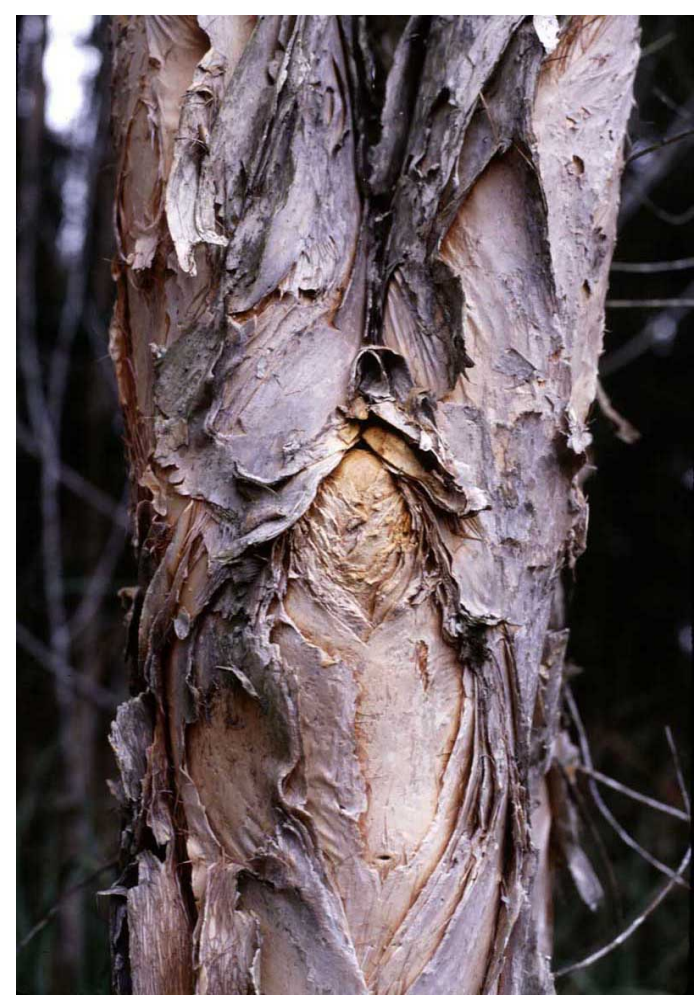

Figure 2. Melaleuca bark.

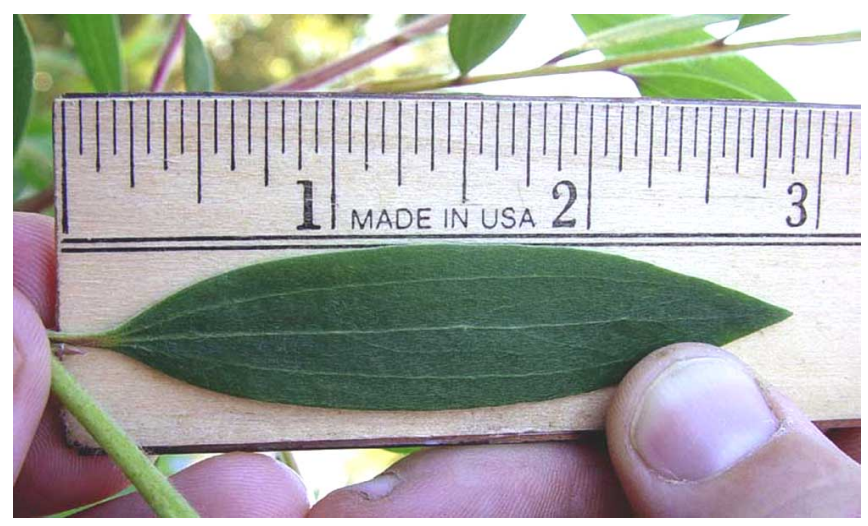

Figure 3. Melaleuca leaf. 


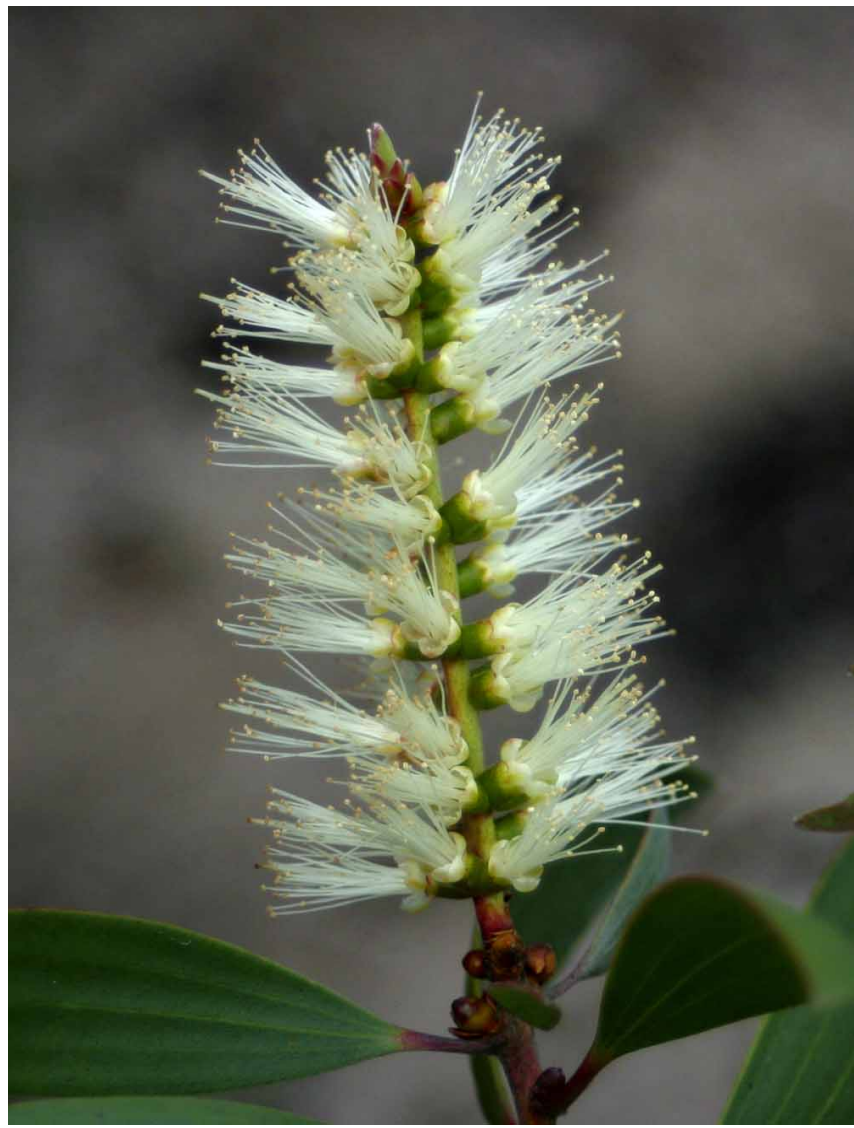

Figure 4. Melaleuca flower.

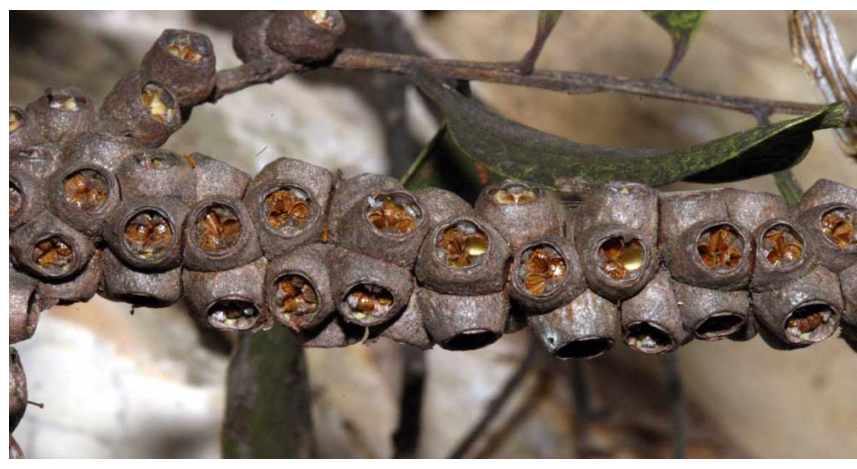

Figure 5. Melaleuca seed capsules.

\section{Integrated Management of Melaleuca}

\section{Biological Controls}

Biological control is using a pest's natural enemies to lower its population. When melaleuca was introduced into Florida, it was done without any of the insects or pathogens from Australia that attack the tree and help to limit its numbers. Researchers have studied the insect populations in Australia and identified many species that feed on melaleuca. However, of those insects found damaging melaleuca, only those that are proven to be non-harmful to desirable plants will be released for melaleuca control in the United States. Two insects have shown promise in integrated management of melaleuca: the melaleuca weevil (Oxyops vitiosa) (Figure 6) released in 1997 and the melaleuca psyllid (Boreioglycaspis melaleucae) (Figure 7) released in 2002. The bud-gall fly (Fergusonina turneri) was released in 2005 and is being evaluated by USDA researchers. Although these insects are not expected to kill mature melaleuca trees, it is hoped they will reduce tree vigor, seed production, and establishment of seedlings. Biological controls spread from tree to tree on their own and the melaleuca weevil and melaleuca psyllid are present in most areas of the state where melaleuca occurs. Conditions such as extreme cold and standing water can reduce their populations, but the insect populations will eventually rebound in melaleuca infested areas when favorable conditions resume.

Another insect that attacks melaleuca is the lobate lac scale (Paratachardina lobata lobata) (Figure 8). This is an invasive insect native to India and Sri Lanka that was first found in Broward County in 1999. Note: lobate lac scale should not be confused with biological control agents deliberately released to control melaleuca. Evidence of the lac scale includes a dark, sooty mold covering leaves and high numbers of minute, bark-like bumps or scales on twigs. This insect is not only destructive to melaleuca but also to many ornamental plantings and native vegetation. Information on how to control lac scale in the landscape can be obtained from your County Cooperative Extension Service.

\section{Mechanical Controls}

Logging equipment and heavy-duty mowing equipment are sometimes used for removing melaleuca trees. Mechanical removal is expensive and causes soil disturbance, which is conducive to re-infestation by melaleuca and other invasive species. This method is usually used for land clearing for development, and removal along canal, roadside, and utility rights-of-way. Mechanical removal is generally not used for melaleuca control on private property. 


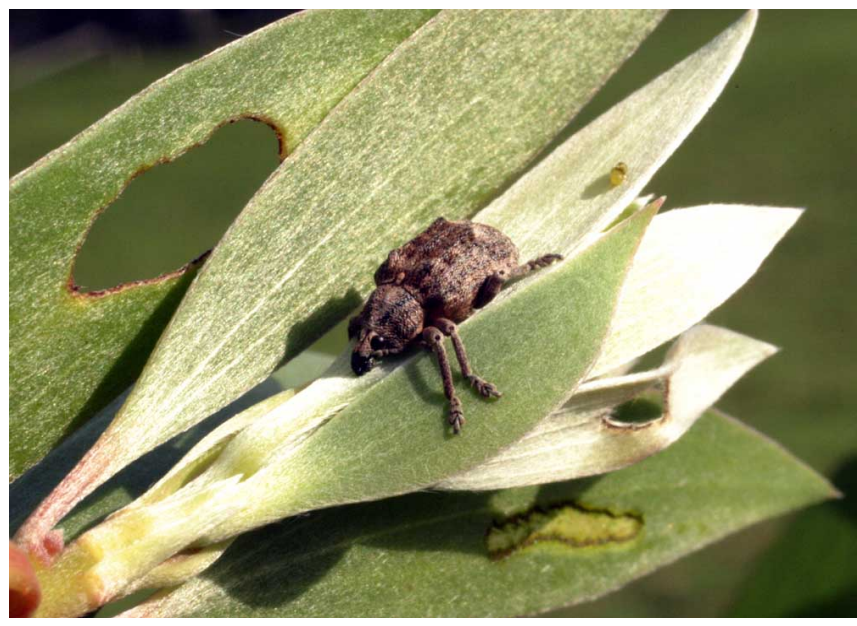

Figure 6. Melaleuca weevil (Oxyops vitiosa).

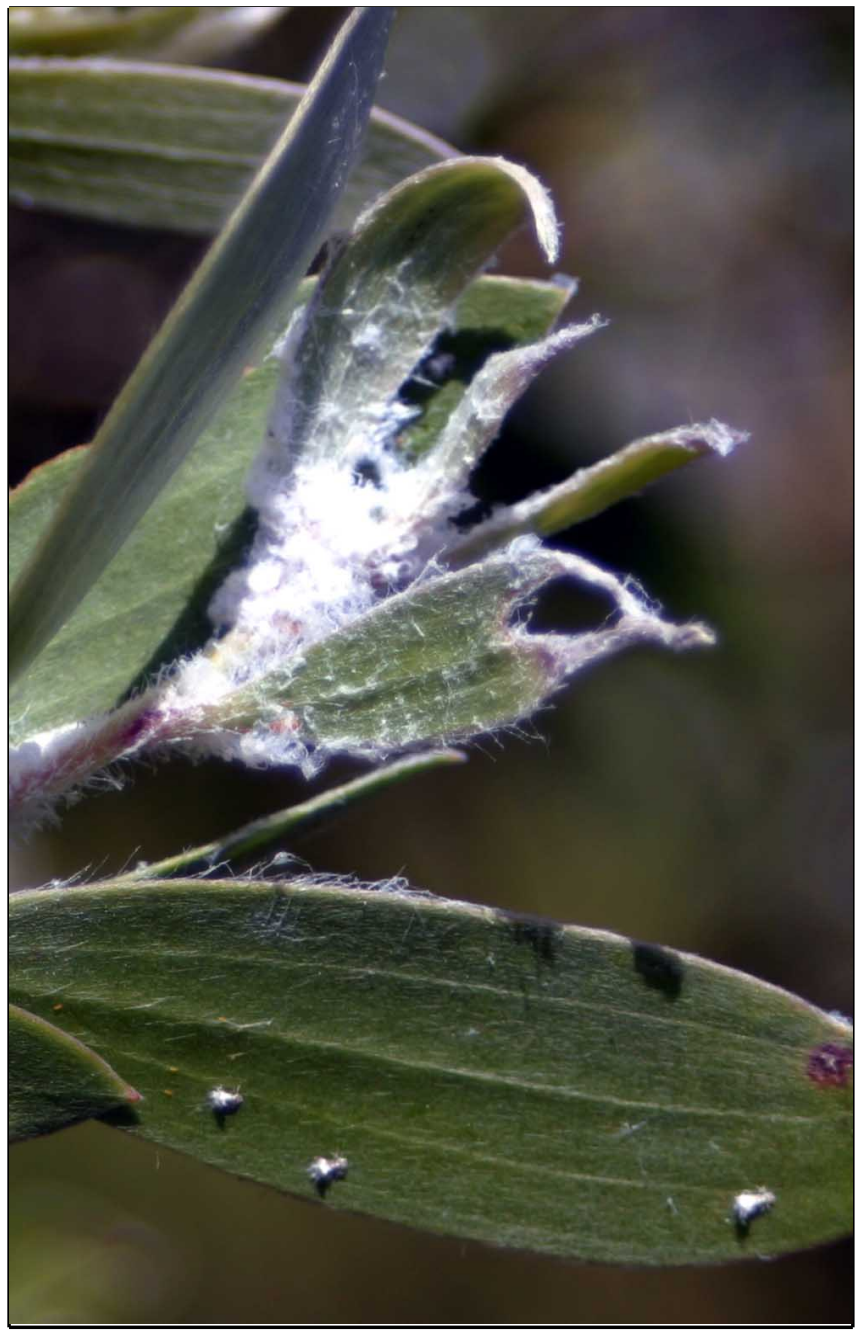

Figure 7. Melaleuca psyllids (Boreioglycaspis melaleucae) excrete a white substance (flocculence) that indicates their presence on melaleuca.

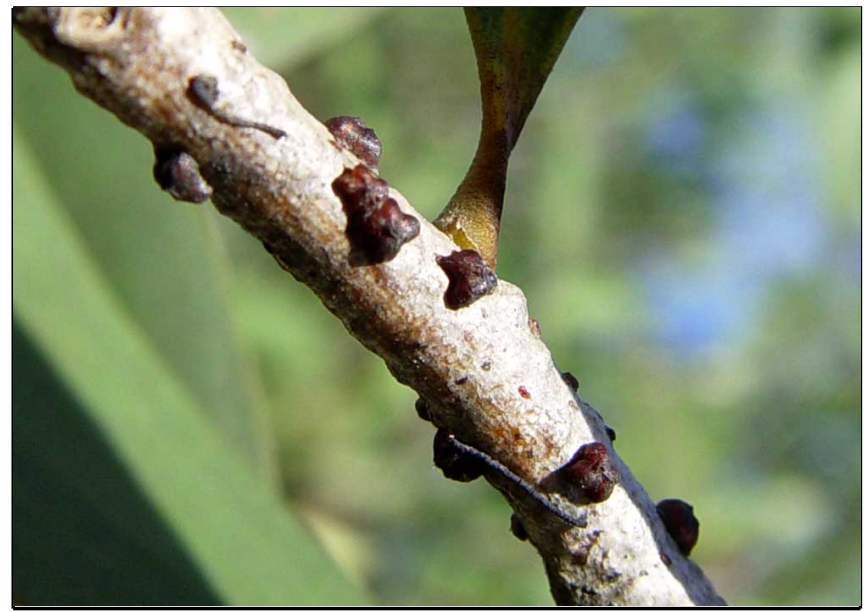

Figure 8. Lobate Lac Scale (Paratachardina lobata lobata) on melaleuca.

\section{Herbicides}

Herbicides are used for killing, individual or populations of melaleuca trees. To control dense populations of mature melaleuca trees, state and federal agencies apply herbicides with the active ingredients glyphosate and imazapyr by helicopter. These herbicides, which can be absorbed through the leaves, can also be applied with hand-held equipment to control seedling and sapling trees. Glyphosate and imazapyr can kill native/non-targeted plants when leaves come in contact with these herbicides and imazapyr can also kill plants when roots come in contact with it. Therefore, helicopter applications are only made to dense stands of melaleuca where few to no non-target plants exist. When applying herbicide to seedlings and saplings in areas where desirable vegetation exists, care must be taken to apply the herbicide only to the melaleuca.

Individual trees can be killed by applying herbicide to the trees using a technique known as frill-and-girdle (or hack-and-squirt) (Figure 9). Frill-and-girdle involves cutting away the tree's thick bark and applying a herbicide mixture of imazapyr or imazapyr and glyphosate to the living portion of the trunk (cambium), which is just inside the bark and just outside of the wood (Figure 10). This technique leaves the trees standing, which can be unsightly and potentially hazardous when trees decay and fall.

When it is undesirable to leave trees standing, they can be felled, but regrowth will usually occur from the stump. To prevent regrowth, herbicide is 


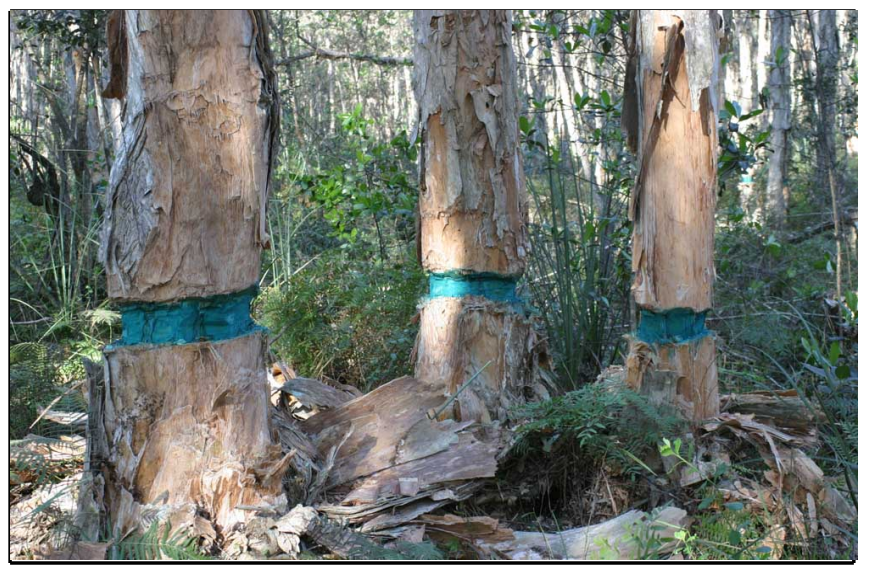

Figure 9. Herbicides applied to melaleuca using the frill-and-girdle, or hack-and-squirt, technique. Application areas have been dyed blue.

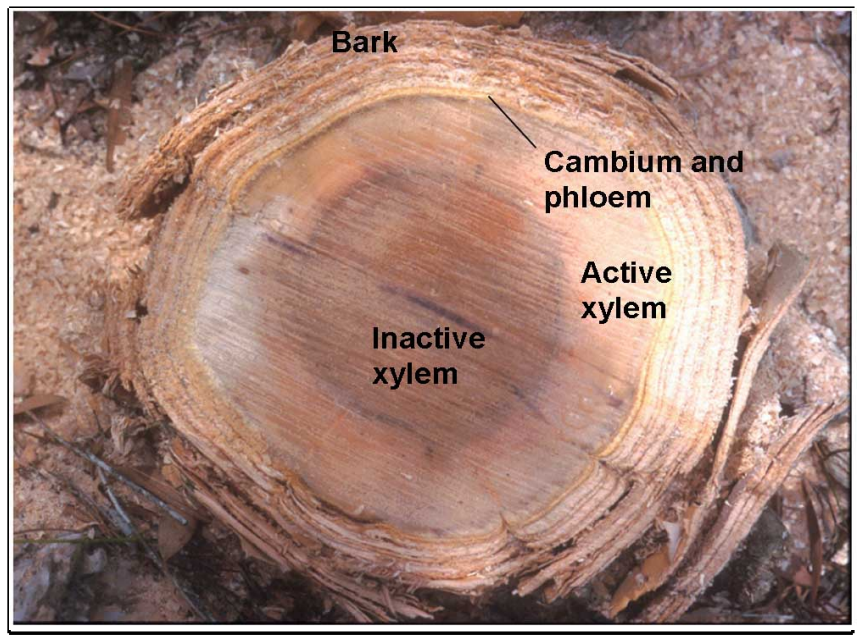

Figure 10. Herbicide should be applied to the cambium, which is the layer between the phloem and bark.

applied to the fresh cut (Figure 11). This method is time consuming and labor intensive, but has the advantage that trees are not left standing. Land management agencies usually use a herbicide product that contains imazapyr for treating melaleuca stumps. Imazapyr is readily absorbed by the roots of plants and can kill desirable plants if it comes in contact with their roots. Therefore, it is not recommended for use in landscapes.

\section{Control Methods for Homeowners}

Control methods that can be used by private property owners to rid their property of melaleuca trees are similar to those used by professional land managers but will be different in scale. Property owners with large numbers of melaleuca trees are advised to consult a professional weed management company or a local agency for assistance. Property

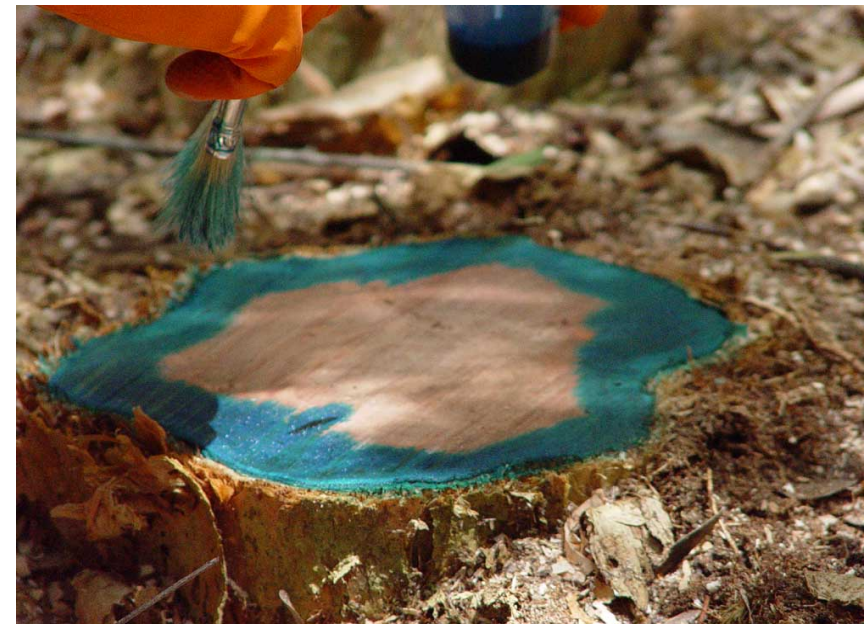

Figure 11. When applying herbicide to a cut ctump, it need only be applied to the phloem and cambium (seen here after dye was added to the solution).

owners with a small number of trees will probably want to cut the trees down or have them cut down by a professional tree trimming company. Grinding the stumps may prevent regrowth but can be expensive. Treating the stumps with herbicide to prevent regrowth is less laborious, less expensive, results in less soil disturbance, and provides consistent results. Property owners can use glyphosate or triclopyr-containing herbicide products, which can be obtained from retail garden stores that are conveniently packaged for homeowner use and available in small quantities for homeowners who have only small numbers of stumps to treat. A concentrated glyphosate-containing product (e.g. Roundup Super Concentrate) will provide the most consistent results. A triclopyr-containing product (e.g Brush Killer Concentrate or Brush-B-Gon) can also be used but with less consistent results. Stumps should be cut to within 4 inches of the ground and level so that herbicide does not run off.

Approximately 6 ounces of herbicide per 10 inches of stump diameter should be applied and concentrated near the living portion of the stump (cambium), which is located just inside the bark. Herbicide should be applied within fifteen minutes of felling the tree. If a large number of stumps are treated, herbicide should be applied when rainfall is not expected for 24 hours, but if only a small number of stumps are treated they can be covered with waterproof material to prevent rainfall from washing the herbicide from the stump. 


\section{What You Can Do}

- Learn to recognize melaleuca and how it is controlled.

- If you have melaleuca on your property, remove it.

- Dispose of melaleuca debris where it will be incinerated or buried deep in a landfill, or where seedlings and vegetative growth can be destroyed.

- Inform others about the problems caused by having melaleuca on their property and encourage them to remove it.

- Persuade government officials to have melaleuca removed from public property.

\section{Additional Information}

County Cooperative Extension Office http://extension.ifas.ufl.edu

UF Institute of Food and Agricultural Sciences Electronic Data Information Service http://edis.ifas.ufl.edu

UF Center for Aquatic and Invasive Plants http://plants.ifas.ufl.edu

Florida Department of Environmental Protection Bureau of Invasive Plant Management http://www.dep.state.fl.us/lands/invaspec/

Florida Exotic Pest Plant Council http://www.fleppc.org

The Areawide Management and Evaluation (TAME) of Melaleuca

http://tame.ifas.ufl.edu

Literature citations are omitted from this document but a comprehensive literature review of melaleuca is presented in:

Serbesoff-King, K. 2003. Melaleuca in Florida: a literature review on the taxonomy, distribution, biology, ecology, economic importance and control measures. J. Aquat. Plant Manage. 41:98-112.

\section{Related EDIS Publications}

Help Protect Florida's Natural Areas from Non-Native Invasive Plants: http://edis.ifas.ufl.edu/AG108

Control of Non-native Plants in Natural Areas of Florida: http://edis.ifas.ufl.edu/WG209

Ecological Consequences of Invasion by Melaleuca Quinquenervia in South Florida Wetlands: Paradise Damaged, not Lost: http://edis.ifas.ufl.edu/UW123

Biological Control Containment Facilities in Florida: http://edis.ifas.ufl.edu/IN509

Biological Control with Insects: The Melaleuca Snout Beetle: http://edis.ifas.ufl.edu/AG022

Classical Biological Control of Weeds with Insects: Melaleuca Weevil: http://edis.ifas.ufl.edu/IN172

Dispersal of Oxyops vitiosa: A Biological Control Agent of Melaleuca in Florida: http://edis.ifas.ufl.edu/IN497

Melaleuca Snout Beetle, Melaleuca Weevil (unofficial common names), Oxyops vitiosa (Pascoe) (Insecta: Coleoptera: Curculionidae): http://edis.ifas.ufl.edu/IN368

Biological Control with Insects: The Melaleuca Psyllid: http://edis.ifas.ufl.edu/AG169

A Psyllid, Boreioglycaspis melaleucae Moore (Insecta: Hemiptera: Psyllidae): http://edis.ifas.ufl.edu/IN495

Lobate Lac Scale, Paratachardina lobata lobata (Chamberlin) (Hemiptera: Sternorrhyncha:

Coccoidea: Kerriidae):

http://edis.ifas.ufl.edu/IN471

La Escama Lobada de Laca, Paratachardina lobata (Chamberlin) (Insecta: Hemiptera: Sternorrhyncha: Coccoidea: Kerriidae): http://edis.ifas.ufl.edu/IN586

Landscape Mulches: What Are The Choices in Florida?: http://edis.ifas.ufl.edu/FR079 